\title{
OPTIMALISASI POWER POINT UNTUK PEMBELAJARAN MATEMATIKA DENGAN KOMBINASI MATH TYPE DAN GRAPH 4.4.2 SERTA VIDEOSCRIBE
}

\author{
NurulLita Sari' ${ }^{1}$, Tabah Heri Setiawan²), Tri Utami Ningsih ${ }^{3)}$, Khorijiah ${ }^{4)}$, Deana \\ Nurul Khaeva ${ }^{5}$, Vidtiya Eka Putri6) \\ 1,2,3,4,5,6Program Studi Matematika, Fakultas MIPA, Universitas Pamulang
}

\begin{abstract}
Abstrak
Dampak adanya pandemi Covid-19 seperti saat berdampak pada segala sektor salah satunya dunia pendidikan dimana aktifitas belajar mengajar di sekolah ditiadakan demi memutus mata rantai virus corona dan menggantinya dengan kegiatan belajar dan mengajar dari rumah secara daring. Guru ditantang untuk dapat memberikan sebuah pembelajaran dengan berbasis daring dengan memadukan sistem sinkronus dan asinkronus. Sinkronus dapat dilakukan dengan tatap muka virtual dan dialog langsung via ruang obrolan. Selain itu juga diperlukan metode asinkronus supaya dapat diakses oleh peserta didik dimanapun dan kapanpun dalam bentuk modul digital, video pembelajaran, slide dan lain sebagainya. Dengan diadakannya pelatihan ini diharapkan dapat menambah kompetensi guru khususnya guru matematika SMK se-Kota Depok untuk membuat serta menyusun slide pembelajaran matematika yang menarik, rapi, interaktif dan komunikatif dengan mengoptimalkan power point sebagai media pembelajaran dan membuat video animasi pembelajaran matematika dengan menggunkanan videoscribe.
\end{abstract}

Keywords: graph 4.4.2, mathtype, power point, sinkronus-asincronus, videoscribe

\begin{abstract}
The impact of the Covid-19 pandemic is like when it affects all sectors, one of which is the world of education where teaching and learning activities in schools are eliminated in order to break the chain of the corona virus and replace them with learning and teaching activities from home online. Teachers are challenged to be able to provide an online-based learning by combining synchronous and asynchronous systems. Synchronization can be done with virtual face-to-face and live dialogue via chat rooms. In addition, an asynchronous method is also needed so that it can be accessed by students anywhere and anytime in the form of digital modules, learning videos, slides and so on. With the holding of this training, it is hoped that it can increase the competence of teachers, especially SMK mathematics teachers in Depok City to create and compile attractive, neat, interactive and communicative mathematics learning slides by optimizing power points as learning media and making animated videos of mathematics learning using videoscribe..
\end{abstract}

Keywords: graph 4.4.2, mathtype, power point, synchronous - asincronus, videoscribe 


\section{PENDAHULUAN}

Pandemi covid-19 yang mulai melanda Indonesia sejak awal maret 2020 (the Guardian, 2020) membawa perubahan arah pembelajaran yang semula dilakukan secara tatap muka langsung sebagaimana umumnya. Demi memutus rantai penyebaran virus corona maka pemerintah melalui kemendikbud dalam surat edarannya agar seluruh satuan pendidikan untuk dapat melaksanakan pembelajaran secara daring melalui skema pembelajaran jarak jauh (Kemdikbud, 2020).

Pendidikan jarak jauh sendiri telah diatur dalam UU Sisdiknas 2003 Bagian Ke-10 Pasal 31 yang berbunyi: "(1) Pendidikan jarak jauh dapat diselenggarakan pada semua jalur, jenjang, dan jenis pendidikan. (2) Pendidikan jarak jauh berfungsi memberikan layanan pendidikan kepada kelompok masyarakat yang tidak dapat mengikuti pendidikan secara tatap muka atau reguler. (3) Pendidikan jarak jauh diselenggarakan dalam berbagai bentuk, modus, dan cakupan yang didukung oleh sarana dan layanan belajar serta sistem penilaian yang menjamin mutu lulusan sesuai dengan standar nasional pendidikan. (4) Ketentuan mengenai penyelenggaraan pendidikan jarak jauh sebagaimana dimaksud dalam ayat (1), ayat (2), dan ayat (3) diatur lebih lanjut dengan Peraturan Pemerintah" (Kemdikbud, n.d.).

Dengan konsep baru seperti saat ini maka dituntut baik pihak sekolah sebagai penyelenggara pembelajaran daring maupun guru sebagai tenaga pendidik untuk dapat memberikan pembelajaran yang kolaboratif dan interaktif. Dalam pembelajaran jarak jauh dengan konsep daring dikenal dengan 2 model yakni model sinkronus (synchronous ) dan asinkronus (asynchronous), dimana dengan kedua model dapat diterapkan secara sendiri-sendiri maupun bersamaan (Oztok et al., 2013).

Model pembelajaran daring sinkronus merupakan komunikasi langsung dalam waktu yang bersamaan antara guru dan siswa melalui media daring. Metode ini mirip dengan belajar seperti layaknya belajar di sekolah hanya saja ruangnya bersifat maya. Beberapa teknik yang dapat digunakan dalam metode ini seperti konferensi video (video conference), panggilan video (video call), dan obrolan langsung (chatting). Saat ini sudah banyak tersedia alat atau aplikasi untuk dapat menjalankan pembelajaran sinkronus misalnya aplikasi Zoom, Google Meet, Cisco Webex, WhatsApp, Telegram, dan aplikasi lainnya. (Setiawan, 2021)

Sedangkan untuk model pembelajaran daring asinkronus komunikasi yang dibangun tidak secara langsung dan interaksi antar peserta didik maupun dengan pendidik bersifat non iteraktif. Prinsip kerja dari asinkronus ini adalah sekolah menyediakan konten secara online dan siswa dapat dapat mengakses konten itu kapanpun dan dimanapun. Teknik yang dapat dilakukan pada pembelajaran daring asinkronus seperti video pembelajaran, modul belajar mandiri, tugas, dan forum diskusi yang umumnya diletakan pada sebuah Learning Management System (LMS) seperti Moodle, Schoology, Edmodo, Google Classroom dan semisalnya. (Setiawan, 2021)

Guru-guru matematika SMK di Kota Depok yang tergabung dalam wadah Musyawarah Guru Mata Pelajaran (MGMP) Matematika SMK Kota Depok umumnya melakukan pembelajaran daring dengan memadukan antara model sinkronus dengan asinkronus. Dengan memadukan antara model sinkronus dan asinkronus dari beberapa penelitian seperti yang dilakukan oleh Jackson (2012), Offir, dkk (2008) serta Shahabadi dan Uplane (2015) terbukti bahwa dengan memadukan model pembelajaran daring sinkronus dan asinkronus dapat meningkatkan kualitas pembelajaran, terlebih pada pembelajaran daring di masa pandemi covid-19 ini penggabungan kedua model 
cukup membantu peserta didik dalam memahami materi yang disampaiakn oleh guru. Meskipun demikian, ada beberapa kendala jika menggabungkan kedua model pembelajaran daring yakni guru dituntut untuk membuat media pembelajatan yang lebih banyak dan mudah dipahami oleh peserta didik. Disi lain guru harus mereangkan materi secara langsung, disis lain guru juga harus menyiapkan beberapa media untuk dipelajari secara mandiri.

Mengingat pentingnya media pembelajaran digital pada proses pembelajaran daring ini maka Program Studi Matematika Fakultas MIPA Universitas Pamulang bekerja sama dengan MGMP Matematika SMK Kota Depok menyelenggarakan pelatikan pembuatan media pembelajaran dengan judul "Optimalisasi Power Point Untuk Pembelajaran Matematika Dengan Kombinasi Mathype Dan Graph 4.4.2 Serta Videoscribe".

Mengapa dipilih Microsoft Power Point dikarenakan aplikasi ini sangat populer di masyarakat sebagai aplikasi presentasi yang handal dan baik, hal ini dikarenakan Microsoft Power Point dirancang khusus untuk mampu menampilkan program multimedia menarik, mudah dalam pembuatan, mudah dalam penggunaan dan relatif murah (Rusman et al., 2012). Microsoft Power Point merupakan program aplikasi presentasi yang populer dan paling banyak digunakan saat ini untuk berbagai kepentingan presentasi, baik pembelajaran, presentasi produk, meeting, seminar, lokakarya dan sebagainya. Dalam penelitian yang dilakukan oleh Misbahudin dkk (2018) dengan menggunakan Microsoft Power Point untuk pembelajaran diperoleh hasil: (1) peserta didik lebih mengerti pada materi yang disampaikan guru, (2) peserta didik lebih konsentrasi dan aktif dalam proses pembelajaran, (3) memaksimalkan rencana pembelajaran.

Meskipun demikian masih banyak guru khusunya untuk mata pelajaran matematika belum mengoptimalkan penggunaan Microsoft Power Point dalam membuat media pembelajaran. Banyak dijumpai slide yang dihasilkan cenderung monoton serta kurang dinamis sehingga menyebabkan kebosanan dan kejenuhan pada peserta didik. Selain itu tampilan pada rumus dan grafik belum terlihat profesional dan menarik. Oleh karena itu dalam guru-guru perlu dilatih untuk membuat slide salah satunya dengan memadukannya dengan MathType dan Graph 4.4.2. Fungsi MathType untuk membuat rumus atau formula matematika dalam bentuk persamaan dan sebagainya, sedangkan Graph 4.4.2 berfungsi untuk membangun grafik dari sebuah persamaan (Setiawan \& Maulani, 2019) dan sangat cocok digunakan untuk materi yang terdapat unsur geometri (Setiawan, 2019).

Dengan mengoptimalkan semua menu yang ada di Microsoft Power Point disertai kolaborasi dengan MathType dan Graph 4.4.2 maka media ini dapat dijadikan media pembelajaran baik untuk sinkronus maupun asinkronus. Saat tatap muka secara virtual slide power point dapat ditampilkan melalui sharescreen (berbagi tampilan), dan asinkronusnya dengan menguploadnya kembali ke dalam LMS dengan terlebih dahulu mengubah kedalam bentuk video melalui menu konversi video atau rekam desktop.

Selain Microsoft Power Point, media yang cukup populer saat ini adalah dalam bentuk video penjelas (explainer video) dan salah satu perangkat lunak yang digunakan untuk membuat video penjelas adalah VideoScribe. VideoScribe merupakan perangkat lunak yang dapat digunakan dalam membuat video animasi berlatar putih dengan sangat mudah. Menurut Sutrisno (2016) VideoScribe merupakan sarana yang baik untuk pengembangan belajar mandiri di rumah maupun di sekolah. Sifatnya sebagai explainer 
video, maka VideoScribe sangat membantu pendidik dalam memberikan materi dalam bentuk video animasi (Yusup et al., 2016).

Oleh karena itu kami melakukan Pengabdian kepada Masyarakat (PkM) berupa pelatihan dan pendampingan pembuatan media pembelajaran matematika dengan judul pengabdian "Optimalisasi Power Point Untuk Pembelajaran Matematika Dengan Kombinasi Mathype Dan Graph 4.4.2 Serta VideoScribe" untuk guru-guru matematika SMK se-Kota Depok. Diharapkan dengan adanya pelatihan ini maka guru-guru yang tergabung dalam MGMP Matematika SMK Kota Depok dapat melaksanakan Kegiatan Belajar Mengajar (KBM) dengan maksimal dan dapat mencapai tujuan pembelajaran yang diharapkan selama pandemi Covid-19 dan dapat berbagi dengan sesama guru baik dalam satu gugus maupun dalam satu wilayah.

\section{METODE PELAKSANAAN}

Metode pelaksanaan kegiatan pengabdian kepada masyarakat ini melalui skema pelatihan dan pendampingan terhadap guru-guru matematika SMK se-Kota Depok dalam pembuatan media pembelajaran matematika dengan menggunakan Microsoft Power Point dan VideoScribe serta mengombinasikannya dengan MathType dan Graph 4.4.2.

Kegiatan pelatihan dan pendampingan ini dilaksanakan secara daring maupun luring. Peserta kuring dibatasi hanya 50 orang termasuk panitia, sedangkan sisanya mengikuti via Zoom yang telah disediakan oleh panitia. Untuk kegiatan luring dilaksanakan di SMK Taruna Bhakti Kota Depok. Kegiatan dilaksanakan selama 3 hari secara beruntun mulai tanggal 28 Oktober 2020 sampai dengan 30 Oktober 2020 dengan total peserta berjumlah 93 peserta

Hasil dari pelatihan ini adalah berupa kumpulan slide pembelajaran dari masingmasing peserta yang nantinya dikumpulkan oleh MGMP Matematika SMK sebagai bank materi dan dapat diakses untuk semua guru matematika SMK khususnya di Kota Depok. Diakhir sesi peserta juga wajib mengisi kuesioner sebagai salah satu upaya timbal balik dari kegiatan yang sudah dilaksanakan dan syarat untuk mendapatkan sertifikat pelatihan yang dikeluarkan oleh pihak Universitas Pamulang.

\section{HASIL DAN PEMBAHASAN}

Kegiatan pelatihan dan pendampingan dilaksanakan dalam bentuk inkuiri-proyek dimana peserta diberikan materi atau gambaran awal, kemudian dilanjutkan dengan langkah-langkah pembuatan media pembelajaran dengan mengenalkan penggunaan MathType dan Graph 4.4.2, kemudian setelah peserta menguasai materi MathType dan Graph 4.4.2 dilanjutkan dengan pembuatan materi pembelajaran dengan Microsoft Power Point, setelah mahir dilanjutkan dengan VideoScribe. 


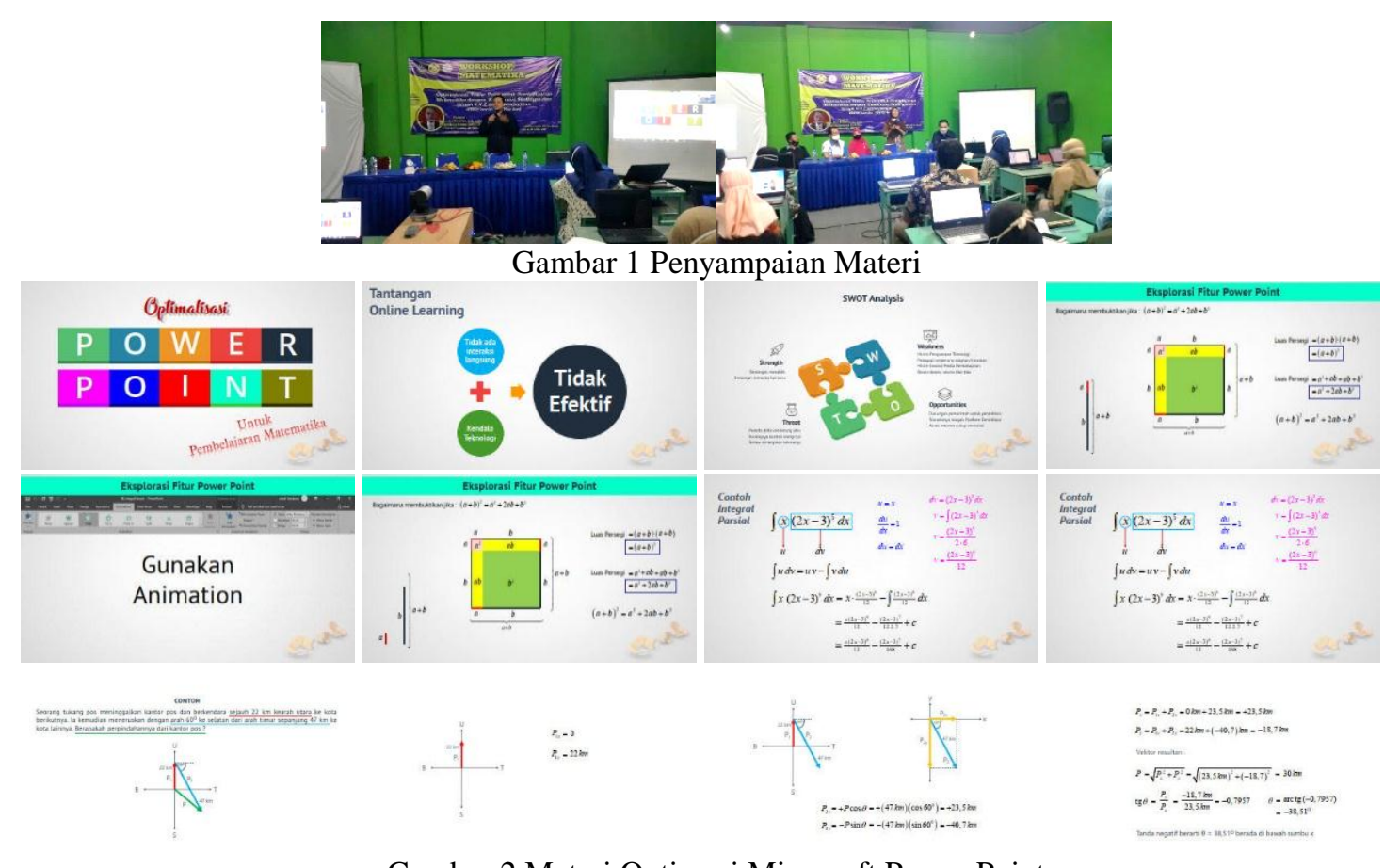

Gambar 2 Materi Optimasi Microsoft Power Point

Seusai acara pelatihan dan pendampingan, peserta mengisi angket digital melalui google form untuk mengukur tingkat kepuasan peserta terhadap acara yang berlangsung selama 3 hari dengan hasil sebagai berikut:

1. Bagaimana kepuasan saudara mengenai metode atau cara penyampaian narasumber dalam kegiatan pengabdian yang telah dilaksanakan?

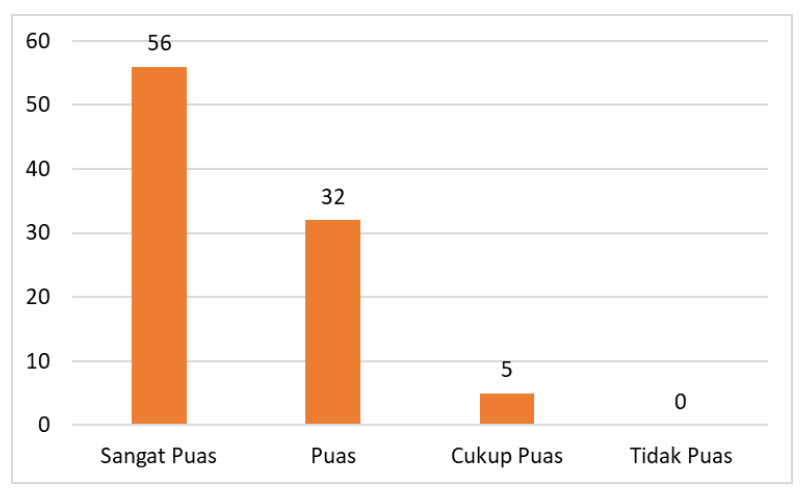

2. Bagaimana kepuasan saudara mengenai pelaksanaan kegiatan pengabdian yang telah dilaksanakan oleh tim PS Matematika FMIPA Universitas Pamulang?

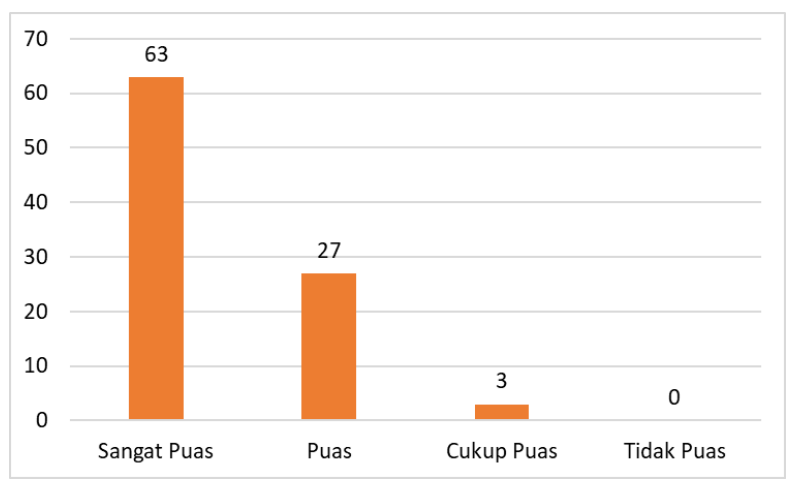


3. Bagaimana pendapat saudara mengenai kebermanfaatan kegiatan pengabdian yang telah dilaksanakan?

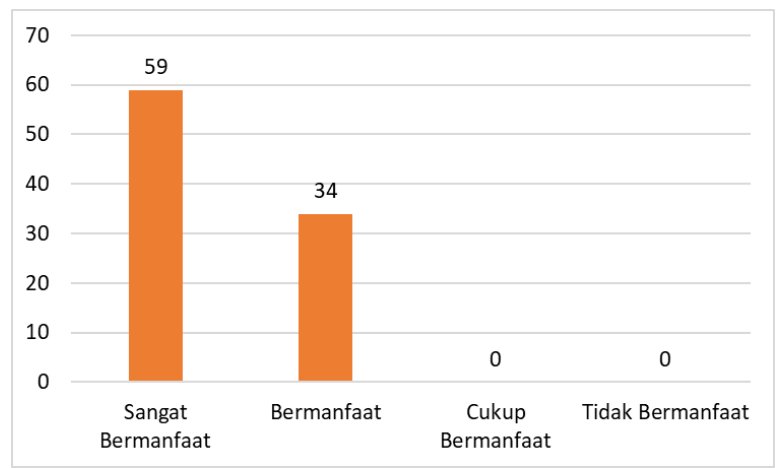

4. Apakah kegiatan pengabdian yang telah dilaksanakan dapat dilanjutkan oleh mitra pengabdian?

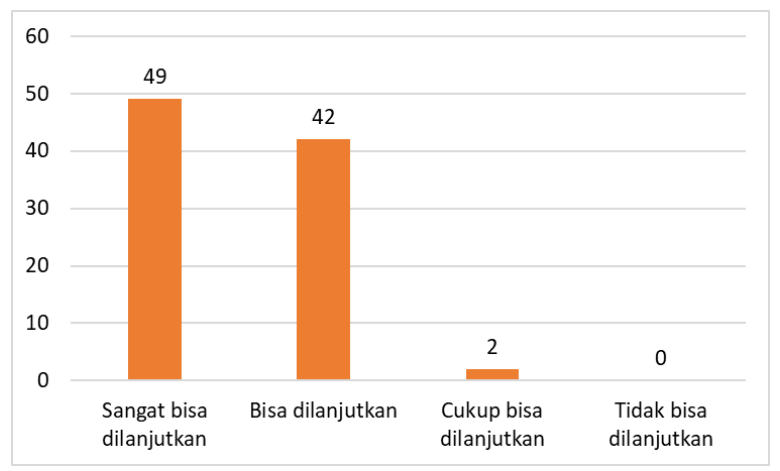

\section{SIMPULAN}

Berdasarkan pengamatan secara kualitatif terhadap umpan balik (feedback) melalui angket digital yang diisi oleh peserta, dapat disimpulkan bahwa pembuatan media pembelajaran dengan Microsoft Power Point maupun VideoScribe dapat dilakukan dengan kombinasi MathType dan Graph 4.4.2, sehingga memudahkan pendidik/guru matematika dalam proses penyampaian materi secara daring baik malului model sinkronus maupun model asinkronus.

\section{DAFTAR PUSTAKA}

Jackson, D. (2012). Synchronous Versus Asynchronous Online Courses: An Introduction for Perioperative Nurses Returning to School. Perioperative Nursing Clinics, 7(2), 161-169. https://doi.org/10.1016/j.cpen.2012.02.001

Kemdikbud. (n.d.). UU No. 20 Tahun 2003 Tentang Sistem Pendidikan Nasional. Retrieved January 29, 2021, from http://simkeu.kemdikbud.go.id/index.php/peraturan1/8-uu-undang-undang/12uu-no-20-tahun-2003-tentang-sistem-pendidikan-nasional 
Optimalisasi Power Point Untuk Pembelajaran Matematika Dengan Kombinasi Math Type Dan Graph

Kemdikbud. (2020). Mendikbud Terbitkan SE tentang Pelaksanaan Pendidikan dalam Masa Darurat Covid-19. https://www.kemdikbud.go.id/main/blog/2020/03/mendikbud-terbitkan-setentang-pelaksanaan-pendidikan-dalam-masa-darurat-covid19

Misbahudin, D., Rochman, C., Nasrudin, D., \& Solihati, I. (2018). Penggunaan Power Point Sebagai Media Pembelajaran: Efektifkah? WaPFi (Wahana Pendidikan Fisika), 3(1), 43-48. https://doi.org/10.17509/wapfi.v3i1.10939

Offir, B., Lev, Y., \& Bezalel, R. (2008). Surface and deep learning processes in distance education: Synchronous versus asynchronous systems. Computers \& Education, 51(3), 1172-1183. https://doi.org/10.1016/j.compedu.2007.10.009

Oztok, M., Zingaro, D., Brett, C., \& Hewitt, J. (2013). Exploring asynchronous and synchronous tool use in online courses. Computers \& Education, 60(1), 87-94. https://doi.org/10.1016/j.compedu.2012.08.007

Rusman, Kurniawan, D., \& Riyana, C. (2012). Pembelajaran Berbasis Teknologi Informasi dan Komunikasi. Rajawali Pers.

Setiawan, T. H. (2019). Pemanfaatan Software Graph 4.4.2. Dalam Menunjang Perkuliahan Geometri Analitik. STATMAT: JURNAL STATISTIKA DAN MATEMATIKA, 1(2), Article 2. https://doi.org/10.32493/sm.v1i2.2945

Setiawan, T. H. (2021, January 9). Menyambut Pembelajaran Daring di Tahun 2021. BantenNews.co.id. https://www.bantennews.co.id/menyambut-pembelajarandaring-di-tahun-2021/

Setiawan, T. H., \& Maulani, A. (2019, January 24). Panduan Graph 4.4.2 [Monograph]. Unpam Press. http://eprints.unpam.ac.id/8597/

Shahabadi, M. M., \& Uplane, M. (2015). Synchronous and Asynchronous e-learning Styles and Academic Performance of e-learners. Procedia - Social and Behavioral Sciences, 176, 129-138. https://doi.org/10.1016/j.sbspro.2015.01.453

Sutrisno, T. (2016). Pengembangan Media Videoscribe Berbasis E-Learning pada Mata Pelajaran Komunikasi Data dan Interface di SMK Sunan Drajat Lamongan. Jurnal Pendidikan Teknik Elektro, 5(3).

The Guardian. (2020, March 2). First coronavirus cases confirmed in Indonesia amid fears nation is ill-prepared for outbreak. The Guardian. http://www.theguardian.com/world/2020/mar/02/first-coronavirus-casesconfirmed-in-indonesia-amid-fears-nation-is-ill-prepared-for-outbreak

Yusup, M., Aini, Q., \& Pertiwi, K. D. (2016). Media Audio Visual Menggunakan Videoscribe Sebagai Penyajian Informasi Pembelajaran Pada Kelas Sistem Operasi. Technomedia Journal, 1(1), 126-138. 